\title{
From social ties to embedded competencies: the case of business groups
}

\author{
Pursey P. M. A. R. Heugens · Stelios C. Zyglidopoulos
}

Published online: 15 July 2008

(C) The Author(s) 2008

\begin{abstract}
Our current views of economic competition are still rooted in the imagery of the isolated firm that transacts with its buyers, suppliers, and competitors via largely anonymous factor and product markets. Yet this view is fundamentally at odds with the growing importance of business groups in the global economy. We thus need a reconceptualized version of our idea of economic competition, which is capable of explaining competitive advantage at the group-versus-group rather than firm-versusfirm level of analysis. In the present paper we build on insights derived from organizational sociology and organizational economics to develop a business group-level theory of competition and competitive advantage based on embedded competencies.
\end{abstract}

Keywords Resource-based view - Competitive advantage .

Discrete competencies · Embedded competencies · Business groups ·

Profit redistribution rules

\section{The discrete organizational perspective}

The idea that business organizations are bundles of idiosyncratic resources and resource conversion activities is central to the resource-based view (RBV) of the

A previous version of this paper was presented at the 21st EGOS Colloquium, June 30-July 2, 2005, Berlin, Germany.

P. P. M. A. R. Heugens ( $\square)$

Rotterdam School of Management, Erasmus University, PO Box 1738, 3000 DR Rotterdam, The Netherlands

e-mail: pheugens@rsm.nl

S. C. Zyglidopoulos ( ()

The Judge Business School, University of Cambridge, Trumpington Street,

Cambridge CB2 1AG, UK

e-mail: szyglidopoulos@yahoo.com 
firm (Rumelt 1984). The perspective accounts for inter-firm performance differentials by examining how economic rents derive from resources and capabilities that are valuable, inimitable, and non-substitutable (Barney 1991; Dierickx and Cool 1989; Lippman and Rumelt 1982). The perspective is isolationist, because the RBV suggests that the process of economic value creation is dependent on a firm's ability to seal off its most valuable assets from competitors' attempts at imitating or purchasing those resources. In this paper we refer to this position in RBV theorizing as the discrete organizational perspective.

The view of economic competition that underlies the discrete organizational perspective centers on head-to-head clashes between materially independent firms. This view is fundamentally at odds with the increasing importance of business groups- "sets of legally separate firms bound together in persistent formal and/or informal ways" (Granovetter 2005, p. 429)—in the contemporary economy. Three examples suffice to make this point. First, in China, the business group is currently experiencing a meteoric rise. In restructuring the Chinese economy, Chinese reformers have closely studied business groups in other Asian countries, and have begun building Chinese versions of these conglomerates from the mid-1980s onwards (Keister 1998). In particular, Korean chaebols have inspired Chinese reformers to promote kin-based linkages across separate ventures (cf. Chang 2003), whereas Japanese keiretsu have set the example for linkages based on cross-venture lending, trade, shareholding, and director dispatch (cf. Lincoln and Gerlach 2004). Second, in many of the former communist countries in Eastern Europe and Central Asia, managers are currently breaking up large formerly state-owned firms into numerous interdependent joint stock and limited liability companies. They do this to deal with bad debts, the threats of bankruptcy, and declining sales (Kornai 1992; Stark 1996). Third, even in the mature economies of North America and Western Europe, business group-like corporate structures are on the increase, due to the persistent growth in number and magnitude of strategic alliances and other forms of cross-corporate collaboration (Gulati 1999; Gulati et al. 2000; Kogut 1988). These three trends combined clearly reduce the empirical domain of the discrete RBV. How can the theory be adapted to explain the type of economic competition we find in business group-dominated contexts, and the competitive advantage of the business groups themselves?

We suggest that the discrete RBV requires a revision in order to increase its fit with an increasingly business group-intensive economy (cf. Lavie 2006). Specifically, an extension of the perspective is needed that: (a) accounts for the boundaryspanning properties of competencies within business groups, and (b) explains how such competencies can contribute to the performance of business groups in their entirety. We offer such an extension in the current paper, after we present a concise overview of the scope conditions pertaining to our analysis. Like all scientific work, the conceptual analysis presented here builds on a number of prior contributions that explore how interfirm ties contribute to the development and exploitation of competitive resources (cf. Almeida and Kogut 1999; Dyer and Singh 1998; Eisenhardt and Schoonhoven 1996; Foss and Eriksen 1995; Gulati 1999; Gulati et al. 2000; Lavie 2006; McEvily and Marcus 2005; Shan et al. 1994; Sorensen and Reve 1998; Uzzi 1997; Zajac and Olsen 1993). What all of these contributions have in common, however, is that they are reluctant to do away with the discrete 
perspective altogether. Their focus remains on the competitiveness implications of network ties for individual firms. In contrast, we lift the level of the analysis of competitive advantage from firm-versus-firm to group-versus-group.

\section{Scope conditions: business group prevalence and profitability}

The value of our analysis is potentially bounded by two scope conditions. A first scope condition is business group prevalence. The alternative to the discrete organizational perspective we develop here is essentially a resource-based theory of sustainable competitive advantage at the business group level. Hence, if business groups were a sporadically occurring phenomenon, the value of our analysis would be limited on the whole. Relatedly, if business group prevalence would largely be restricted to certain geographic regions, then our analysis would only be applicable to those regions. A second scope condition is business group profitability. An underlying premise of our analysis is that the business group is an inherently attractive organizational form, which is in no way 'hardwired' to underperform stand-alone firms. If business group performance would systemically lag behind that of unaffiliated firms, any project aiming to explain group-level competitive advantages would necessarily be limited in its relevance.

To explore our first scope condition (prevalence), we compiled an overview which synthesizes the prevalence of the business group organizational form in relation to the proportion of stand-alone firms for 38 different countries around the globe (see Table 1). The second column of this table shows the proportion of firms in a given nation that are affiliated with a business group. On average, no less than $43.9 \%$ of all firms in a given country are not stand-alone firms, but durably affiliated with a business group. Moreover, due to a lack of full data for certain economies (such as the US), these estimates are also rather conservative. In other words, business groups are not a sporadically occurring phenomenon, but rather a prominent feature of the global competitive landscape. These data thus provide support for our project of developing a 'friendly amended' version of the RBV that is able to explain the performance of business groups.

According to received insights in the business group literature, however, this organizational form may not be as prevalent in mature markets as it is in developing nations. More in particular, the influential 'institutional voids' thesis holds that business groups are more prevalent in emerging markets like Brazil, India, or China, because of their capacity to fill the deficiencies in the matrix of business-relevant background institutions that were created by a rapidly but often unevenly developing nation-state (Khanna and Palepu 2004; Whitley 1999). Institutional voids theoreticians point out that business groups have the capacity to internalize failing institutions, such as the markets for venture capital and managerial talent, by redistributing resources over the individual firms comprising the group according to their needs and prospects. Consequentially, business groups are likely to be more prominent in nations with deficient background institutions. To test whether the presence of institutional voids is a relevant scope condition for our project, we correlate business group prevalence with a widely used indicator for institutional 
Table 1 The prevalence and profitability of business groups

\begin{tabular}{|c|c|c|c|c|}
\hline Country & $\begin{array}{l}\text { Prevalence } \\
\text { groups (\%) }\end{array}$ & $\begin{array}{l}\text { Absolute } \\
\text { profitability } \\
(\%)\end{array}$ & $\begin{array}{l}\text { Relative } \\
\text { profitability }\end{array}$ & $\begin{array}{l}\text { Rule } \\
\text { of law }\end{array}$ \\
\hline Argentina & $51^{\mathrm{d}}$ & $4.9^{\mathrm{d}}$ & $-(* *)^{\mathrm{d}, \mathrm{h}}$ & $-0.58^{g}$ \\
\hline Australia & $30^{\mathrm{a}}$ & - & - & $1.81^{\mathrm{g}}$ \\
\hline Austria & $28^{\mathrm{c}}$ & - & - & $1.87^{\mathrm{g}}$ \\
\hline Belgium & $65^{\mathrm{c}}$ & - & - & $1.45^{\mathrm{g}}$ \\
\hline Brazil & $48^{\mathrm{d}}$ & $5.0^{\mathrm{d}}$ & n.s. ${ }^{\mathrm{d}}$ & $-0.48^{\mathrm{g}}$ \\
\hline Canada & $15^{\mathrm{a}}$ & - & - & $1.85^{\mathrm{g}}$ \\
\hline Chile & $36^{\mathrm{d}}$ & $8.0^{\mathrm{d}}$ & $-(*)^{\mathrm{d}}$ & $1.15^{\mathrm{g}}$ \\
\hline Denmark & $68^{\mathrm{c}}$ & - & n.s. ${ }^{f}$ & $2.03^{\mathrm{g}}$ \\
\hline Finland & $69^{\mathrm{c}}$ & - & - & $1.95^{\mathrm{g}}$ \\
\hline France & $58^{\mathrm{c}}$ & - & $+(* *)^{\mathrm{f}}$ & $1.31^{\mathrm{g}}$ \\
\hline Germany & $32^{\mathrm{c}}$ & - & n.s. ${ }^{f}$ & $1.77^{\mathrm{g}}$ \\
\hline Greece & $25^{\mathrm{c}}$ & - & - & $0.64^{\mathrm{g}}$ \\
\hline Hong Kong & $25^{\mathrm{b}}$ & - & n.s. ${ }^{\mathrm{e}}$ & $1.45^{\mathrm{g}}$ \\
\hline India & $49^{\mathrm{d}}$ & $10.8^{\mathrm{d}}$ & $+(* *)^{\mathrm{d}}$ & $0.17^{\mathrm{g}}$ \\
\hline Indonesia & $67^{\mathrm{b}}$ & $9.3^{\mathrm{d}}$ & $+(* *)^{\mathrm{d}}$ & $-0.82^{\mathrm{g}}$ \\
\hline Ireland & $37^{\mathrm{c}}$ & - & - & $1.62^{\mathrm{g}}$ \\
\hline Israel & $33^{\mathrm{d}}$ & $9.0^{\mathrm{d}}$ & $+(*)^{\mathrm{d}}$ & $0.69^{\mathrm{g}}$ \\
\hline Italy & $55^{\mathrm{c}}$ & - & n.s. ${ }^{f}$ & $0.37^{\mathrm{g}}$ \\
\hline Japan & $36^{\mathrm{b}}$ & - & n.s. ${ }^{\mathrm{e}}$ & $1.40^{\mathrm{g}}$ \\
\hline Malaysia & $39^{\mathrm{b}}$ & - & - & $0.58^{\mathrm{g}}$ \\
\hline Mexico & $32^{\mathrm{d}}$ & $8.1^{\mathrm{d}}$ & n.s. ${ }^{d}$ & $-0.49^{\mathrm{g}}$ \\
\hline Netherlands & $67^{\mathrm{c}}$ & - & n.s. ${ }^{f}$ & $1.75^{\mathrm{g}}$ \\
\hline New Zealand & $25^{\mathrm{a}}$ & - & - & $1.93^{\mathrm{g}}$ \\
\hline Norway & $41^{\mathrm{c}}$ & - & n.s. ${ }^{\mathrm{f}}$ & $2.02^{\mathrm{g}}$ \\
\hline Peru & $26^{\mathrm{d}}$ & $3.1^{\mathrm{d}}$ & $+(*)^{\mathrm{d}}$ & $-.75^{\mathrm{g}}$ \\
\hline Philippines & $40^{\mathrm{b}}$ & $6.7^{\mathrm{d}}$ & $-(*)^{\mathrm{d}}$ & $-.48^{\mathrm{g}}$ \\
\hline Portugal & $20^{\mathrm{a}}$ & - & - & $0.97^{\mathrm{g}}$ \\
\hline Singapore & $55^{\mathrm{b}}$ & - & $+(*)^{\mathrm{e}}$ & $1.82^{\mathrm{g}}$ \\
\hline South Africa & $49^{\mathrm{d}}$ & $13.2^{\mathrm{d}}$ & $+(*)^{\mathrm{d}}$ & $0.24^{\mathrm{g}}$ \\
\hline South Korea & $43^{\mathrm{b}}$ & $6.0^{\mathrm{d}}$ & n.s. ${ }^{\mathrm{d}}$ & $0.72^{\mathrm{g}}$ \\
\hline Spain & $46^{\mathrm{c}}$ & - & n.s. ${ }^{f}$ & $1.10^{\mathrm{g}}$ \\
\hline Sweden & $74^{\mathrm{c}}$ & - & n.s. ${ }^{f}$ & $1.86^{\mathrm{g}}$ \\
\hline Switzerland & $60^{\mathrm{c}}$ & - & n.s. ${ }^{\mathrm{f}}$ & $1.96^{\mathrm{g}}$ \\
\hline Taiwan & $49^{\mathrm{b}}$ & $5.3^{\mathrm{d}}$ & $+(* *)^{\mathrm{d}}$ & $0.77^{\mathrm{g}}$ \\
\hline Thailand & $61^{\mathrm{d}}$ & $6.1^{\mathrm{d}}$ & n.s. ${ }^{\mathrm{d}}$ & $0.03^{\mathrm{g}}$ \\
\hline Turkey & $45^{\mathrm{d}}$ & $23.2^{\mathrm{d}}$ & n.s. ${ }^{d}$ & $0.08^{\mathrm{g}}$ \\
\hline UK & $68^{\mathrm{c}}$ & _- & n.s. ${ }^{f}$ & $1.73^{\mathrm{g}}$ \\
\hline
\end{tabular}


Table 1 continued

\begin{tabular}{lllll}
\hline Country & $\begin{array}{l}\text { Prevalence } \\
\text { groups (\%) }\end{array}$ & $\begin{array}{l}\text { Absolute } \\
\text { profitability } \\
(\%)\end{array}$ & $\begin{array}{l}\text { Relative } \\
\text { profitability }\end{array}$ & $\begin{array}{l}\text { Rule } \\
\text { of law }\end{array}$ \\
\hline US & $0^{\mathrm{a}}$ & - & - & $1.57^{\mathrm{g}}$ \\
\hline
\end{tabular}

Sources:

a La Porta et al. (1999, p. 493). Reported is the percentage of the largest 20 widely held firms in which the ultimate owner is another firm with at least a $10 \%$ stake. Data was compiled by summing columns 'Widely held financial' and 'Widely held corporation.' Estimate is often highly conservative, due to the focus on equity ties and the exclusion of family-owned business groups

b Claessens et al. (2000, p. 92). Reported is the percentage of all firms in which the ultimate owner exercises control through at least one widely-held firm. Family-owned business groups are included in this estimate

c Belenzon and Berkovitz (2008, p. 26). Reported is the percentage of all firms affiliated with a business group, with annual sales above one million dollars and with more than 50 employees

d Khanna and Rivkin (2001, pp. 56-57). Reported is the percentage of all publicly listed firms affiliated with a business group; the absolute performance of these firms as measured by their return on assets; and the performance of these firms relative to stand-alone firms

e Heugens et al. (2008). Reported is meta-analytic evidence of the performance of group-affiliated firms relative to stand-alone firms in Asia

${ }^{f}$ Van Essen et al. (2008). Reported is meta-analytic evidence of the performance of group-affiliated firms relative to stand-alone firms in Europe

g Kaufmann et al. (2006). Reported is the rule of law score per country. See the original paper for more details

$\mathrm{h} * *$ Denotes a strongly significant effect, * Denotes a moderately significant effect. See the original papers for more details

development, notably: Kaufmann et al.'s (2006) rule of law variable (see Arndt and Oman 2006, for a critical reading). Column 5 reports the rule of law scores for all countries in our sample. As it turns out, business group prevalence is not significantly correlated to overall institutional development ( $r=.02$; n.s.), implying that business groups do not merely exist to functionally compensate for institutional deficiencies. In other words, the quality of the matrix of background institutions is not a relevant scope condition for our project.

The second scope condition to potentially impinge upon the generalizability of our analysis is the profitability of business group members. Three reasons are commonly stipulated as to why affiliated firms would underperform stand-alone firms (Khanna and Rivkin 2001; Heugens et al. 2008). First, affiliated firms may be exposed to strong social pressures to 'bail out' other firms in the group that are temporarily or structurally facing conditions of lowered competitiveness and profitability. Second, business group members are often made to purchase supplies from their group siblings, irrespective of the quality they deliver. Therefore they often have to make do with inferior inputs. Third, group members' profits may also be siphoned off ('tunneled') by controlling shareholders for private consumption, who thereby reduce the overall performance of affiliates. Undoubtedly, business group members are occasionally confronted with such perverse effects. The question is, however, whether these effects are pervasive enough to make the business group an inferior organizational form. To explore this question, we made an inventory of how firms affiliated with a business group perform relative to stand- 
alone firms (see Table 1). Column 3 presents the absolute profitability level (measured as return on assets) for a select sub-set of countries. More importantly, column 4 displays how group members perform relative to unaffiliated firms. The results show that the suggested negative effects prevail in only three countries. In eight countries, affiliated firms actually significantly outperform their unbounded counterparts, for reasons we shall explore below. In 16 further countries no significant performance differences exist between affiliated and unaffiliated firms. In short, business groups are an attractive organizational form in their own right, and their performance is not a relevant scope condition to our work.

\section{Discrete and embedded definitions of competence}

Our first ambition with this paper is to offer a reconceptualization of the discrete competence perspective, such that it can account for the fact that the competencies of the individual organizations comprising a business group are often highly interwoven and deliberately shared amongst the group's members (Chang 2003; Eisenhardt and Schoonhoven 1996; Granovetter 2005; Kogut 1988). To that end, we first provide a definition of the discrete competencies concept, based on an overview of the prior literature. Next, we introduce the economic-sociological notion of embeddedness (Granovetter 1985; Uzzi 1999) to demonstrate how competencies themselves can be seen as phenomena that are embedded in groups of collaborating organizations. This will result in a definition of embedded competencies.

\subsection{Defining discrete competencies}

Three definitional characteristics of discrete competencies are commonly identified in the literature, notably: competencies' potential to coordinate lower-level resources and capabilities; their ability to span business and product boundaries; and their orientation towards collective goal attainment.

\subsubsection{Coordinating resources and capabilities}

Barnard (1968/1938) observes that a coordination function must underlie joint action by organizational members. Others have extended this observation to include coordination across resources and capabilities. Contemporary strategic management scholars frequently build their definitions of competence around the coordination theme. According to Roos and Von Krogh (1992), researchers should interpret competencies as the coordinated synthesis of a firm's particular task and knowledge systems. Furthermore, through proficient coordination, business firms can enjoy competitive advantages even if their underlying resources are identical to those of their peers (Branzei and Thornhill 2006). As Sanchez et al. (1996) point out, important differences between firms can arise from differences in coordinating the deployments of resources. Competencies in this sense represent a form of 'organizational capital' (Eriksen and Mikkelsen 1996), which assists a firm to integrate even generic resources into idiosyncratic value propositions. 


\subsubsection{Spanning business and product boundaries}

Various authors stress that valuable competencies span multiple businesses and products (Coyne et al. 1997; Foss 1996; Hamel 1994; Hitt and Ireland 1985; Prahalad and Hamel 1990; Rumelt 1994). Competencies can simultaneously be applied to more than one market or business unit, so that they can be leveraged over multiple revenue-generating activities (Itami 1987; Rumelt 1994). For example, "Canon's core competencies in optics, imaging, and microprocessor controls have enabled it to enter, even dominate, markets as seemingly diverse as copiers, laser printers, cameras, and image scanners" (Prahalad and Hamel 1990, p. 83). According to Sanchez et al. (1996, p. 8), a firm can apply its "existing competencies to current or new market opportunities in ways that do not require qualitative changes in the firm's assets or capabilities" (Sanchez et al. 1996, p. 8). The advantages flowing from this kind of competence leveraging are twofold. First, due to their generic and flexible nature, competencies can be deployed in several ways without costly adaptations (Hamel 1994). Second, if competencies already exist elsewhere in the organization, far less time may be required to replicate them internally than to compile them from scratch from generic resources purchased in the market (Markides and Williamson 1994; Winter and Szulanski 2001).

\subsubsection{Goal attainment}

The competitive-teleological orientation of the competence perspective is perhaps its most widely accepted characteristic (Andrews 1971; Coyne et al. 1997; Hitt and Ireland 1985; Markides and Williamson 1994; McGrath et al. 1995; Snow and Hrebiniak 1980). The literature often describes competencies as vehicles for attaining strategic goals (McGrath et al. 1995). We define such goals as gaps between the perceived and the desired state of any of the firm's systemic elements. Such a gap may consist of a difference between mediocre and superb execution of critical processes (Coyne et al. 1997), between average and excellent problemsolving abilities (Foss 1996), or between modest and rapid strategic growth rates. Either way, competencies play an important role in a teleological view on social organization, as it is their purpose to achieve concrete corporate goals or to facilitate the sustenance of a competitive advantage over rivals (Heugens et al. 2006).

Drawing on these three themes, we define discrete competencies as a set of goaloriented learnings, which typically span the boundaries of the firm's multiple products and business units, and which serve to coordinate the firm's underlying resources and capabilities.

\subsection{Defining embedded competencies}

The problem with the above definition of discrete competencies is that it does not adequately capture the skills, resources, and routines employed in the growing section of the contemporary economy that is organized along the lines of business groups. In short, what is needed is an additional definition of embedded 
competencies, which can be used to typify the competencies of groups of nominally independent firms that are nevertheless durably linked through various types of social and economic ties (Eisenhardt and Schoonhoven 1996). The notion of embeddedness in this case "refers to the fact that economic action and outcomes, like all social action and outcomes, are affected by actors' dyadic (pair-wise) relations and by the structure of the overall network of relations" (Granovetter 1993, p. 33).

Characteristic for the notion of embeddedness as it is used in economic sociology is that it frames commercial exchange relationships not as relatively anonymous market ties, but rather as durable webs of social attachments. The durability of such exchanges makes that the identity of the exchange partners becomes important to the exchange, and that the relationship acquires a social character above and beyond the technical characteristics of the exchange at hand (Granovetter 1985). As the exchange loses its anonymity, partners start building relationships in which trust and mutual reliance rise to the fore (Uzzi 1999). No relationship starts out as a strong tie, but embeddedness works as a priming mechanism through which small initial offers of trust and assistance strengthen into a resilient tie, provided that they are reciprocated. At least three characteristics mark embedded ties: trust, fine-grained information transfer, and a collaborative orientation.

\subsubsection{Trust}

Trust exists when "one enters a transaction believing that transaction partners will behave properly for reasons that transcend pure self-interest" (Granovetter 1993, p. 40). The concept entails a belief that one's side is not going to be taken advantage of and that one's partner will give priority to the relationship over narrow self interest (Uzzi 1997). Granovetter (1993) identifies three reasons for the emergence of trust in embedded relationships. First, individuals act in a trustworthy way because they perceive it to be in their social or economic interest to do so. Second, trust arises in exchange relationships when partners believe that it is morally right to trust one another. Finally, trust results when actors start to view it as an essential part of their relationships with transaction partners (Granovetter 1993; Uzzi 1999). Governance by trust both facilitates the exchange of private information and increases the efficiency of economic transactions in general. In Arrow's words, trust "is an important lubricant of a social system. It is extremely efficient: it saves a lot of trouble to have a fair degree of reliance on other people's word" (1974, p. 23).

\subsubsection{Fine-grained information transfer}

Information transfer in embedded relationships "is not only more detailed and tacit [than in arm's length relationships] but has a holistic rather than a divisible structure that is difficult to communicate through market ties" (Uzzi 1997, p. 45). Only embedded ties allow for the transfer of private information (Portes and Sensenbrenner 1993). Private information entails insights as diverse as the locus of where a given actor's specific expertise resides, the nature of the capabilities 
involved in the marketing of a complex product, the major resource dependencies of a given contracting partner, and so forth. Since this kind of information can only be exchanged as the by-product of an ongoing voluntary transfer between durably linked parties, fine-grained information transfer tends to be associated with embedded ties (Kogut 1988; McEvily and Marcus 2005; Uzzi 1997, 1999).

\subsubsection{Collaborative orientation}

A final definitional characteristic of embedded relationships is that they supplant the exchange-centered logic of the arm's length relationship-which centers on direct reciprocation - with a collaborative orientation on both ends of the dyad. When the partners exchange small gestures and minor favors, a mutual system of expectations and pro-social norms emerges over time (Macaulay 1963). Preserving this system subsequently becomes more important to the partners than the completion of any discrete transaction (Williamson 1985). The collaborative orientation that cements embedded ties has two aspects. First, collaboration plays a role in relational problem-solving, in that "embedded ties entail problem-solving mechanisms that enable actors to coordinate functions and work out problems 'on the fly.' These arrangements typically consist of routines of negotiation and mutual adjustment that flexibly resolve problems" (Uzzi 1997, p. 47). Second, a strong collaborative orientation stimulates localized search behavior (Cyert and March 1963). The emergence of embedded ties makes it more likely that firms will search "deep" within their network of relationships to find a collaborative solution to any problem that might appear on the horizon, rather than look outside the network (e.g., in the market) for solutions (Gulati et al. 2000).

For any definition of competencies to have any currency in the context of business groups, it must be reconcilable with the embedded nature of business groups' actions and exchange transactions. Thus, we need to incorporate the notion of embeddedness into our extant definition of competencies. Doing so results in the following adapted definition: embedded competencies are a set of highly transferable goal-oriented learnings, which typically span the boundaries of several formally independent organizations, business units, and products divisions without being "owned" by any of these in particular, and which serve to coordinate underlying resources and capabilities across organizational fault lines.

\section{Embedded competencies and competitive advantage}

Our second ambition with this paper is to put this notion of embedded competencies to work in the context of business groups. Specifically, we aim to arrive at a conceptualization of the resource-based sources of the competitive advantage of business groups. Doing so requires us to elevate the level at which economic competition is assessed from firm-versus-firm to group-versus-group (GomesCasseres 1994). Embedded competencies thus do not benefit individual firms in particular, but business groups in their entirety. In contrast to what the discrete RBV would predict, the value of embedded resources is negatively rather than positively 
related to the extent that they are fully internalized, shielded off from outside inspection, and protected against imitation. Yet, the shared nature of embedded competencies draws our attention to one problem that plays out especially at the interorganizational level of analysis, notably: a problem of collective action with respect to making investments in embedded competencies and dividing up their proceeds. To solve the collective action problem, business groups typically use two instruments: restrictions to group membership and profit redistribution rules for balancing out private and collective gains.

\subsection{Elevating the level of analysis of the RBV}

The reconceptualization of competencies from discrete to embedded entities does not fundamentally alter the logic of the RBV. Theoreticians schooled in the firmversus-firm conception of economic competition (e.g., Amit and Schoemaker 1993; Barney 1991; Rumelt 1984) typically suggest that firms must acquire or develop resources that are valuable (i.e., leading to efficiency gains or other forms of economic quasi-rent); rare (i.e., supply being low as compared to demand); inimitable (i.e., not easily copied by competitors); and organized for success (i.e., purposefully integrated into the organization's administrative architecture).

The group-versus-group conceptualization of economic competition (GomesCasseres 1994) does not discard these four principles. Instead, due to the increasing relevance of business groups to the contemporary economy, we suggest that these principles are best applied at the group-versus-group than at the firm-versus-firm level of analysis. Specifically, the present paper suggests that business groups in their entirety, rather than organizations individually, must seek to attract or develop the sought-after valuable, rare, inimitable, and organized resources. Gaining such embedded competencies allows them to yield sustainable competitive advantages in their struggle against other business groups.

\subsection{Competitive advantage as a problem of collective action}

The observation that business groups, in their guise as networks of formally independent organizations, can collectively control resources that form the basis for resource-based competition with other groups has some descriptive merit (cf. Granovetter 2005). But one important caveat applies, notably: that the private interests of individual group members can threaten the group's ability to create group-level competitive advantages. More specifically, attaining group-level competitive advantages in the presence of private incentives to 'shirk' or 'defect' on collective commitments is hampered by so-called problems of collective action (Olsen 1971). When maximum group-level performance requires sacrifices by every individual member, and when at least some members refrain from making these sacrifices in the hope that others will compensate for them, the group as a whole suffers. Concrete examples of collective action problems in the context of developing embedded competencies have been provided by various authors (Hamel 1991). Each of these examples shows that in the absence of appropriate relational governance 
mechanisms, even minor dissociations between the private and collective benefits of collaboration lead to suboptimal outcomes for the group as a whole.

Collectively, a group of organizations benefits most from a completely unrestricted free flow of competencies throughout the entire business group. Without internal barriers to replication (Winter and Szulanski 2001), all organizations in a group are able to access and adopt the best possible competencies, regardless of where they are located in the business group. The problem, of course, is that business groups are comprised of formally independent organizations that also worry about their private benefits. For each firm individually, the greatest benefits obtain when the other members of the group freely share their competencies with all their counterparts, while the focal organization retains the exclusive right to exploit the specific subset of its own set of resources that is already "best in class" (Hamel 1991).

Attaining group-level competitive advantages is thus a typical problem of collective action, in that it involves a potential clash of collective and private interests that must be neutralized with the help of relational governance mechanisms for Pareto-optimal results to obtain. So how can firms in a business group secure themselves against their fellow group members' pursuit of strictly private benefits? Two relational governance mechanisms are proposed here: restrictions to group access, and profit redistribution rules.

\subsection{Restricting group access}

In this paper, it has been stressed repeatedly that the foundation for embedded competencies consists of thick social ties between business group members (Eisenhardt and Schoonhoven 1996; McEvily and Zaheer 1999; Uzzi 1997). It therefore makes sense to look inside embedded relationships for a solution to the collective action problem. Strict arms-length governance, based on pecuniary incentive alignment and court-enforceable contracts, will rarely form a fruitful basis for capitalizing on embedded competences. The private and collective benefits of such competencies are only produced in business groups characterized by trust, information sharing, and joint problem solving (McEvily and Marcus 2005). As a matter of fact, many business groups operate according to strong principles of solidarity, grounded in kinship, shared ethnicity, religious beliefs, or the regional identity of the grouped businesses (Granovetter 2005). So a first partial solution to the collective action problem consists of keeping solidarity-based business groups tight-knit and exclusive, since unrestricted entry and exit would encourage opportunistic acts and undermine trust.

Business groups across a variety of contexts ensure the exclusivity of their membership, and thereby increase the shadow of the future (Axelrod 1984) for each of the individual business group members, either by restricting or phasing entry to the group. Most modern business groups are organized around kinship ties, core firms, or dominant financiers (Gerlach 1992; Orrù et al. 1996). In each of these instances a limited number of dominant actors - say, a family elder, a flagship firm, or a central bank-can bar prospective new members from entering the business group. But even if entry is granted, initial membership is often not full-fledged. 
Many business groups consist of several hierarchically organized "tiers," which are best conceptualized as "castes" or "classes" in that most of the status and privileges are concentrated in the higher strata, and most of the duties and obligations reside in the lower echelons (Biggart and Guillén 1999; Boisot and Child 1996). Business group entry is typically phased in that new members enter into one of the lower tiers, and can only make it to the higher hierarchical levels after repeated demonstrations of their loyalty and trustworthiness. The preservation of exclusivity via restricted entry thus provides a fertile context for the continued, more or less frictionless exploitation of embedded competencies in the higher tiers of the business group's hierarchy.

\subsection{Profit redistribution rules}

Keeping business groups exclusive is a necessary but not a sufficient condition for overcoming the problem of collectively producing competitive advantage. Exclusivity in business groups puts a "face" on all potential collaborators, and stimulates as well as cements the development of deeply embedded ties. At the same time, resolving the collective action problem requires more than just the screening and socialization of individual members. Specifically, what is needed is a sustainable and mutually attractive balance between individual and collective benefits (Nault and Tyagi 2001), such that members are rewarded for opening up their competencies to other group members and sanctioned when they decide to exclusively pursue their own success. The simplest and most commonly applied approach for 'institutionalizing solidarity' is developing a set of so-called profit redistribution rules. Such rules have been used at the interpersonal level to provide coalitions with staying-power (Simpson and Macy 2001); at the interfirm level to produce solidarity amongst alliance partners (Gedajlovic and Shapiro 2002); and at the state level to keep inefficient firms afloat (Brada et al. 1997).

Prior research on business groups has shown that profit redistribution, whereby stronger firms assist weaker firms by allocating part of their profits to them, is in fact an endemic property of such collectives (Gedajlovic and Shapiro 2002; Khanna and Rivkin 2001). It is tempting to see such profit redistribution practices as a rational insurance scheme, in which profitable firms pay a 'premium' by bailing out firms with weaker performance, such that they can expect help in return in case they experience a temporary slump in profits (cf. Granovetter 2005). Yet the various types of loyalty, solidarity, and obligation that cement the ties in business groups are often hard to reconcile with such a notion grounded in individual rationality. Research by Lincoln and Gerlach (2004) shows that profit redistribution is better interpreted as an instrument that promotes solidarity amongst members and that allows for functional specialization across independently owned firms. Profit redistribution rules play an important role in our analysis of the competitive advantage of business groups, because they provide a rationale for the shared membership of embedded competencies. After all, who 'owns' such competencies in the strict, exclusive sense of the term is largely irrelevant if the profits stemming from them are up for redistribution amongst all members comprising the group. 
Three common profit redistribution rules are available for stimulating the collective use of embedded competencies. The first may be called the fee rule (Nault and Tyagi 2001), which rewards an individual member for making its competencies available by prescribing a fee, to be paid by the user, each time its competencies are accessed and used by another business group member. The second may be called the royalty rule (Nault and Tyagi 2001), which rewards competency-sharing by allowing the original controller of a given competency a share of the user's profits through the installment of a royalty on the latter's sales. The third, and to the Western observer most puzzling rule, may be called the nested hierarchy rule (Chang 1999). The rule states that firms higher up in the structural hierarchy of the group must invest their excess profits in firms lower down in the hierarchy, especially when these firms are troubled or are experiencing difficulties in financing their own investment projects. The crucial point is that these investments in lower-positioned firms are triggered by social obligations rather than purely economic motivations.

Again, these economic governance rules are not in and of themselves sufficient for resolving the problem of collectively attaining competitive advantage, because each rule is in and of itself vulnerable to metering and tampering. But in combination with preexisting embedded ties these rules stimulate the joint attainment of competitive advantage by putting a positive economic incentive on competency sharing in a social environment characterized by trust, information sharing, and joint problem solving.

\section{Conclusion}

The present paper challenges the orthodox view in strategic management that competencies should be uniquely linked to the individual firm in case they are to serve as a basis for competitive advantage. As we have argued, this discrete perspective is less relevant in the contemporary business landscape, in which more and more economically productive activities are organized through the "privately owned social structures" (Chang 1999) of business groups. To come to terms with these developments, we proposed a reconceptualized version of the RBV that aims to explain competitive advantage at the group-versus-group level of analysis rather than at the more traditional firm-versus-firm level.

Two complementary ambitions guided us in writing this paper. A first ambition was to offer a reconceptualization of the traditional discrete competency perspective. At the heart of our new definition lies the conviction that competencies are not a form of organizational capital, but rather a form of social capital - a property of the structure and content of business groups rather than of the strategic architecture of individual firms. A second ambition was to demonstrate how embedded competencies might lead to competitive advantage, given that the aforementioned reconceptualization violates the foundational premise of the discrete RBV. As we have argued, the traditional RBV is still useful for explaining competitive advantage in a group-versus-group situation, albeit with one important caveat. A problem of collective action must be overcome at this level, in the sense that individual group members must receive a proper set of incentives to induce them to freely share their 
competencies with other parties in their business group. This problem of collective action can only be put to rest when sensible profit redistribution rules cemented with embedded social ties provide a sustainable balance between the private and collective benefits to be appropriated by all members of the business group.

Acknowledgements We thank our fellow participants in sub-theme session Elements of social capital: Transformations and transferability for their constructive contribution to our paper. We are also indebted to three anonymous Journal of Management and Governance reviewers and editor Roberto Di Pietra for their insightful comments and editorial guidance. A special word of thanks goes out to Marc van Essen, who helped us collect descriptive data on business group prevalence and relative profitability. Naturally, all remaining errors are our own.

Open Access This article is distributed under the terms of the Creative Commons Attribution Noncommercial License which permits any noncommercial use, distribution, and reproduction in any medium, provided the original author(s) and source are credited.

\section{References}

Almeida, P., \& Kogut, B. (1999). Localization of knowledge and the mobility of engineers in regional networks. Management Science, 45, 905-917.

Amit, R., \& Schoemaker, P. (1993). Strategic assets and organizational rent. Strategic Management Journal, 14, 333-346.

Andrews, K. R. (1971). The concept of corporate strategy. Homewood, IL: Dow Jones-Irwin.

Arndt, C., \& Oman, C. (2006). Uses and abuses of governance indicators. Paris: OECD.

Arrow, K. J. (1974). The limits of organization. New York: John Brockman Associates.

Axelrod, R. M. (1984). The evolution of cooperation. New York: Basic Books.

Barnard, C. (1968/1938). The functions of the executive (2nd ed.). Cambridge, MA: Harvard University Press.

Barney, J. (1991). Firm resources and sustained competitive advantage. Journal of Management, 17(1), 99-120.

Belenzon, S., \& Berkovitz, T. (2008). Business group affiliation, financial development and market structure: Evidence from Europe. Available from SSRN:http://ssrn.com/abstract=1086882.

Biggart, N. W., \& Guillén, M. F. (1999). Developing difference: Social organization and the rise of the auto industries of South Korea, Taiwan, Spain, and Argentina. American Sociological Review, 64, $722-747$.

Boisot, M., \& Child, J. (1996). From fiefs to clans: Explaining China's emerging economic order. Administrative Science Quarterly, 41, 600-628.

Brada, J. C., King, A. E., \& Ma, C. Y. (1997). Industrial economics of the transition: Determinants of enterprise efficiency in Czechoslovakia and Hungary. Oxford Economic Papers, 49, 104-147.

Branzei, O., \& Thornhill, S. (2006). From ordinary resources to extraordinary performance: Environmental moderators of competitive advantage. Strategic Organization, 4(1), 11-41.

Chang, D. (1999). Privately owned social structures: Institutionalization-network contingency in the Korean Chaebol. Ph.D. dissertation, Department of Sociology, University of Chicago.

Chang, S.-J. (2003). The rise and fall of Chaebols: Financial crisis and transformation of Korean business groups. Cambridge: Cambridge University Press.

Claessens, S., Djankov, S., \& Lang, L. H. P. (2000). The separation of ownership and control in East Asian corporations. Journal of Financial Economics, 58, 81-112.

Coyne, K. P., Hall, S. J. D., \& Clifford, P. G. (1997). Is your core competence a mirage? McKinsey Quarterly, (1), 40-55.

Cyert, R. M., \& March, J. G. (1963). A behavioral theory of the firm. Englewood Cliffs, NJ: Prentice Hall.

Dierickx, I., \& Cool, K. (1989). Asset stock accumulation and sustainability of competitive advantage. Management Science, 35(12), 1504-1511. 
Dyer, J. H., \& Singh, H. (1998). The relational view: Cooperative strategy and sources of interorganizational competitive advantage. Academy of Management Review, 23(4), 660-679.

Eisenhardt, K. M., \& Schoonhoven, C. (1996). Resource-based view of strategic alliance formation: Strategic and social effects in entrepreneurial firms. Organization Science, 7, 136-150.

Eriksen, B., \& Mikkelsen, J. (1996). Competitive advantage and the concept of core competence. In N. J. Foss \& C. Knudsen (Eds.), Towards a competence theory of the firm (pp. 54-74). London: Routledge.

Foss, N. J. (1996). Introduction: The emerging competence perspective. In N. J. Foss \& C. Knudsen (Eds.), Towards a competence theory of the firm (pp. 1-12). London: Routledge.

Foss, N. J., \& Eriksen, B. (1995). Competitive advantage and industry capabilities. In C. A. Montgomery (Ed.), Resource-based and evolutionary theories of the firm (pp. 43-69). Boston: Kluwer.

Gedajlovic, E. R., \& Shapiro, D. M. (2002). Ownership structure and firm profitability in Japan. Academy of Management Journal, 45(2), 565-575.

Gerlach, M. L. (1992). Alliance capitalism: The social organization of Japanese business. Berkeley, CA: University of California Press.

Gomes-Casseres, B. (1994). Group versus group: How alliance networks compete. Harvard Business Review, 72(4), 62-74.

Granovetter, M. (1985). Economic action and social structure: The problem of embeddedness. American Journal of Sociology, 91(3), 481-510.

Granovetter, M. (1993). The nature of economic relationships. In R. Swedberg (Ed.), Exploration in economic sociology (pp. 3-41). New York: Russell Sage.

Granovetter, M. (2005). Business groups and social organization. In N. J. Smelser \& R. Swedberg (Eds.), The handbook of economic sociology (2nd ed., pp. 429-450). Princeton: Princeton University Press.

Gulati, R. (1999). Network location and learning: The influence of network resources and firm capabilities on alliance formation. Strategic Management Journal, 20(5), 397-420.

Gulati, R., Nohria, N., \& Zaheer, A. (2000). Strategic networks. Strategic Management Journal, 21(3), 203-215.

Hamel, G. (1991). Competition for competence and interpartner learning within international strategic alliances. Strategic Management Journal, 12, 83-104.

Hamel, G. (1994). The concept of core competence. In G. Hamel \& A. Heene (Eds.), Competence-based Competition (pp. 11-33). New York: Wiley.

Heugens, P. P. M. A. R., Kaptein, S. P., \& van Oosterhout, J. (2006). The ethics of the node versus the ethics of the dyad? Reconciling virtue ethics and contractualism. Organization Studies, 27(3), 391-411.

Heugens, P. P. M. A. R., van Essen, M., \& van Oosterhout, J. (2008). Meta-analyzing ownership concentration and firm performance in Asia: Towards a more fine-grained understanding. Available at SSRN: http://ssrn.com/abstract $=1082175$.

Hitt, M. A., \& Ireland, R. D. (1985). Corporate distinctive competence, strategy, industry, and performance. Strategic Management Journal, 6, 273-293.

Itami, H. (1987). Mobilizing invisible assets. Cambridge, MA: Harvard University Press.

Kaufmann, D., Kraay, A., \& Mastruzzi, M. (2006). Governance matters V: Aggregate and individual governance indicators for 1996-2005. Washington, DC: World Bank.

Keister, L. A. (1998). Engineering growth: Business group structure and firm profitability in China's transition economy. American Journal of Sociology, 104, 404-440.

Khanna, T., \& Palepu, K. (2004). Globalization and convergence in corporate governance: Evidence from Infosys and the Indian software industry. Journal of International Business Studies, 35(6), 484-507.

Khanna, T., \& Rivkin, J. (2001). Estimating the performance effects of business groups in emerging markets. Strategic Management Journal, 22, 45-74.

Kogut, B. (1988). Joint ventures: Theoretical and empirical perspectives. Strategic Management Journal, 9, 319-332.

Kornai, J. (1992). The post-socialist transition and the state: Reflections in the light of Hungarian fiscal problems. American Economic Review, 82(2), 1-21.

La Porta, R., Lopez-de-Silanes, F., \& Shleifer, A. (1999). Corporate ownership around the world. Journal of Finance, 54, 471-517.

Lavie, D. (2006). The competitive advantage of interconnected firms: An extension of the resource-based view. Academy of Management Review, 31, 638-658.

Lincoln, J., \& Gerlach, M. (2004). Japan's network economy: Structure, persistence, and change. Cambridge: Cambridge University Press. 
Lippman, S. A., \& Rumelt, R. P. (1982). Uncertain imitability: An analysis of interfirm differences in efficiency under competition. The Bell Journal of Economics, 13, 418-438.

Macaulay, S. (1963). Non-contractual relations in business: A preliminary study. American Sociological Review, 28, 55-67.

Markides, C. C., \& Williamson, P. J. (1994). Related diversification, core competences and corporate performance. Strategic Management Journal, 15, 149-165.

McEvily, B., \& Marcus, A. (2005). Embedded ties and the acquisition of competitive capabilities. Strategic Management Journal, 26, 1033-1055.

McEvily, B., \& Zaheer, A. (1999). Bridging ties: A source of firm heterogeneity in competitive capabilities. Strategic Management Journal, 20, 1133-1156.

McGrath, R., MacMillan, I. C., \& Venkatraman, S. (1995). Defining and developing competence: A strategic process paradigm. Strategic Management Journal, 16, 251-275.

Nault, B. M., \& Tyagi, R. K. (2001). Implementable mechanisms to coordinate horizontal alliances. Management Science, 47, 787-799.

Olsen, M. (1971). The logic of collective action: Public goods and the theory of groups. Cambridge: Harvard University Press.

Orrù, M., Biggart, N. W., \& Hamilton, G. G. (1997). The economic organization of East Asian capitalism. Thousand Oaks, CA: Sage.

Portes, A., \& Sensenbrenner, J. (1993). Embeddedness and immigration: Notes on the social determinants of economic action. American Journal of Sociology, 98, 1320-1350.

Prahalad, C. K., \& Hamel, G. (1990). The core competence of the corporation. Harvard Business Review, 68(3), 79-91.

Roos, J., \& Von Krogh, G. (1992). Figuring out your competence configuration. European Management Journal, 10(4), 422-427.

Rumelt, R. P. (1984). Towards a strategic theory of the firm. In R. B. Lamb (Ed.), Competitive strategic management (pp. 556-571). Englewood Cliffs, NJ: Prentice-Hall.

Rumelt, R. P. (1994). Foreword. In G. Hamel \& A. Heene (Eds.), Competence-based competition (pp. xvxix). Chichester: Wiley.

Sanchez, R., Heene, A., \& Thomas, H. (1996). Introduction: Towards the theory and practice of competence-based competition. In R. Sanchez, A. Heene, \& H. Thomas (Eds.), Dynamics of competence-based competition: Theory and practice in the new strategic management (pp. 1-35). Oxford: Elsevier Science.

Shan, W., Walker, G., \& Kogut, B. (1994). Interfirm cooperation and startup innovation in the biotechnology industry. Strategic Management Journal, 15, 387-394.

Simpson, B., \& Macy, M. W. (2001). Collective action and power inequality: Coalitions in exchange networks. Social Psychology Quarterly, 64, 88-100.

Snow, C. C., \& Hrebiniak, L. G. (1980). Strategy, distinctive competence, and organizational performance. Administrative Science Quarterly, 25, 317-336.

Sorensen, H. B., \& Reve, T. (1998). Forming strategic alliances for asset development. Scandinavian Journal of Management, 14(3), 151-165.

Stark, D. (1996). Recombinant property in East European capitalism. American Journal of Sociology, 101(4), 993-1027.

Uzzi, B. (1997). Social structure and competition in interfirm networks: The paradox of embeddedness. Administrative Science Quarterly, 42(1), 35-67.

Uzzi, B. (1999). Social embeddedness in the creation of financial capital. American Sociological Review, 64, 481-505.

Van Essen, M., Heugens, P. P. M. A. R., \& van Oosterhout, J. (2008). Meta-analyzing ownership concentration and firm performance in Europe: Towards a more fine-grained understanding. Available at SSRN: http://ssrn.com/abstract $=1082175$.

Whitley, R. (1999). Divergent capitalisms: The social structuring and change of business systems. Oxford: Oxford University Press.

Williamson, O. E. (1985). The economic institutions of capitalism: Firms, markets, relational contracting. New York: Free Press.

Winter, S. G., \& Szulanski, G. (2001). Replication as strategy. Organization Science, 12(6), 730-743.

Zajac, E. J., \& Olsen, C. P. (1993). From transactional cost to transactional value analysis: Implications for the study of interorganizational strategies. Journal of Management Studies, 30(1), 131-145. 


\section{Author Biographies}

Pursey P. M. A. R. Heugens is Professor of Organization Theory at the Rotterdam School of Management, Erasmus University. He holds a $\mathrm{PhD}$ from the same institution, and was previously appointed at the John Molson School of Business, Concordia University and at the Utrecht School of Economics, University of Utrecht. Pursey serves on the editorial boards of six scholarly journals. His research interests include bureaucratic and institutional theories of organization; comparative corporate governance; and management, ethics, and governance of professional service firms.

Stelios C. Zyglidopoulos is University Lecturer in Strategy at the Judge Business School, University of Cambridge. He holds a PhD from McGill University, and was previously appointed at the Rotterdam School of Management, Erasmus University and at the College of Business, Rochester Institute of Technology. Stelios serves on the editorial boards of Corporate Reputation Review and Organization Studies. His research interests include management of corporate reputation, corporate social responsibility and performance; organizational imprinting and evolution; and internationalization of high-tech clusters. 